\title{
Formulation of complementary feeding biscuits with yellowfin fish flour (Thunnus albacares) and terubuk flour (Saccharum edule Hasskarl) to improve nutritional status of children in Papua
}

\author{
${ }^{1}$ Manik, D.I.B., ${ }^{1,2}$ Nuryanto, ${ }^{1,2}$ Panunggal, B. and ${ }^{1,2 *}$ Afifah, D.N. \\ ${ }^{1}$ Department of Nutrition Science, Faculty of Medicine, Universitas Diponegoro, Jl. Prof H. Soedarto, SH, \\ Tembalang, Semarang 50275, Indonesia \\ ${ }^{2}$ Center of Nutrition Research (CENURE), Universitas Diponegoro, Jl. Prof H. Soedarto, SH, Tembalang, \\ Semarang 50275, Indonesia
}

\begin{abstract}
Article history:
Received: 29 December 2019

Received in revised form: 14

February 2020

Accepted: 17 February 2020

Available Online: 30 May

2020
\end{abstract}

\section{Keywords:}

Biscuits,

Complementary feeding,

Yellowfin fish flour,

Terubuk flour

\section{DOI:}

https://doi.org/10.26656/fr.2017.4(S3).S08

\begin{abstract}
The yellowfin fish and terubuk were still rarely used in Papua. This study aimed to determine the physicochemical properties of complementary feeding biscuit formulated with yellowfin fish flour and terubuk flour to improve the nutritional status of children in Papua. A completely randomized single factor-experimental study by using three formulations of yellowfin fish flour and terubuk flour, F1 (1:3), F2 (1:1), and F3 (3:1) was conducted. The carbohydrate content was analyzed with by the difference method, fat by Soxhlet method, protein by Kjeldahl method, fiber by gravimetry method, iron and phosphorus by spectrophotometry method. The physical properties in terms of density, reconstitution and texture were conducted. Sensory evaluation was conducted to determine the acceptance of complementary feeding biscuits. Data were analyzed using the One-Way ANOVA test, Kruskall-Wallis test, Tukey test and Mann-Whitney test. Complementary feeding biscuits F1, F2 and F3 contained energy (435.58; 426.85; 436.71 $\mathrm{kcal})$, protein $(13.86 ; 15.75 ; 17.33 \mathrm{~g})$, carbohydrate $(23.19 ; 24.79 ; 20.45 \mathrm{~g})$, fat $(20.58$; $20.40 ; 20.62 \mathrm{~g})$, fiber $(26.22 ; 20.63 ; 25.25 \mathrm{~g})$, iron $(3.76 ; 4.03 ; 3.68 \mathrm{mg})$, and phosphorus $(267.70 ; 266.36 ; 275.79 \mathrm{mg})$. Complementary feeding biscuits had the following physical properties: density $(0.64 ; 0.68 ; 0.70 \mathrm{~g} / \mathrm{mL})$, reconstitute test $(20 ; 20 ; 25 \mathrm{~mL})$ and texture test $(468.78 ; 299.55 ; 408.05 \mathrm{gf})$. The complementary feeding biscuit was accepted by the panelists. The recommended serving size of complementary feeding biscuit with yellowfin fish flour and terubuk flour was $45 \mathrm{~g}$ or four pieces of biscuit needed to fulfill the required $30 \%$ of children's protein per day.
\end{abstract}

\section{Introduction}

Based on the Basic Health Research 2018, a description of the nutritional status of malnutrition, undernutrition, short and very short of children in Papua Province based on the weight for age, height for age, and weight for height index, respectively $15.6 \%, 30.8 \%$ and $10.2 \%$ (Ministry of Health Republic of Indonesia, 2018). One of the efforts that can be done to reduce the nutritional problems in children is the additional food provision from local food (Rachmawati and Ampera, 2016). This is per WHO/UNICEF recommendation to achieve optimal growth and development for infants and children. WHO/UNICEF stated that: (i) exclusive breastfeeding (without food and other drinks) should be given to infants immediately after birth until 6 months of age; (ii) provide complementary feeding to infants from
6 months to 2 years; and (iii) continuation of breastfeeding until the children are 2 years or older. The recommendation also stated that the complementary feeding shall be made from local food of cheaper cost and abundant (World Health Organization, 2012). Complementary feeding can be processed traditionally or instant. Instant complementary feedings that sold in the market are porridge and biscuit which is easy to prepare in a short time. At the age of one year, the appropriate complementary feeding should not only fulfill the nutritional needs of the baby but also stimulate the baby's feeding skills. Biscuits can train the baby to grasp and bite. Its rehydration capability allows them to be diluted into porridge (Zulfa and Rustanti, 2013).

Papua Province is one area that has a high diversity of biological resource, including local food. Papua's local 
foods which are major and easy to get are yellowfin fish and terubuk. Yellowfin fish is almost available daily at the local market is a protein provider for the community. Yellowfin fish contains high energy, protein, fat, vitamins and minerals, especially iron $(78 \mathrm{mg} / 100 \mathrm{~g})$. Iron has a role for infant and children in the formation of hemoglobin as an oxygen carrier, energy formation and immune system booster. Iron in newborns is a natural supply and help in the process of growth and development, but after 6 months, supplies begin decreasing which is why the intake of iron from additional food is needed. Meanwhile, terubuk is a type of sugarcane (Saccharum edule) which has a lot of variety and types in Jayapura district, Papua. Terubuk contains high energy, protein, fat, vitamins and minerals especially phosphorus $80 \mathrm{mg} / 100 \mathrm{~g}$ (DKBM, 2014). Phosphorus with calcium has a role for infants and children in preventing calcification of bone and teeth, regulate the energy transferring in metabolism, and acid bases body fluid balance. Yellowfin fish and terubuk are both locally abundant sources which can be considered as an alternative ingredient to make complementary foods that can improve the nutritional status of children in Papua. This study is aimed to develop a complementary feeding biscuit made from yellowfin fish flour and terubuk flour and to determine the physicochemical properties of the biscuit.

\section{Materials and methods}

The experimental design of this study was a completely randomized single factor-experimental using three formulations, F1 (1: 3 ratio of yellowfin fish flour to terubuk flour), F2 (1: 1 ratio of yellowfin fish flour to terubuk flour); F3 (3: 1 ratio of yellowfin fish flour to terubuk flour). A total of three repetitions was carried out for each formulation.

\subsection{Formula preparation}

The main ingredient of this complementary feeding biscuit was wheat flour with the substitution of yellowfin fish flour and terubuk flour. Other ingredients were margarine, powder sugar, cornstarch, yolk, butter and skim milk. The difference between formulations can be seen in Table 1 .

The yellowfin fish flour was made by separating meat from the skin, washed, and steamed for $1 \mathrm{hr}$. Cooked fish meat was dried under the sun for 2-3 days before grinding to powder using a blender and sifted with 60-mesh sieve (Jayadiet al., 2018; Utomoet al., 2013)

Terubuk flour was made by separating terubuk from its kelobot that wrapped it. The terubuk was dried under the sun for 2-3 days, ground with a blender and sifted with 60-mesh sieve to obtain the flour.

Table 1. Ingredients of Formula 1, Formula 2, and Formula 3 (\%)

\begin{tabular}{lccc}
\hline Ingredient & Formula 1 & Formula 2 & Formula 3 \\
\hline Yellowfin fish flour & 7.75 & 10.34 & 12.93 \\
Terubuk flour & 12.93 & 10.34 & 7.75 \\
Wheat flour & 17.24 & 17.24 & 17.24 \\
Margarine & 8.62 & 8.62 & 8.62 \\
Powder sugar & 12.93 & 12.93 & 12.93 \\
Cornstarch & 8.62 & 8.62 & 8.62 \\
Yolk & 14.65 & 14.65 & 14.65 \\
Butter & 8.62 & 8.62 & 8.62 \\
Skim milk & 8.62 & 8.62 & 8.62 \\
\hline
\end{tabular}

Complementary feeding biscuit was made by mixing margarine, sugar, corn starch, yolk, butter, and skim milk together. The yellowfin fish flour, terubuk flour and wheat flour were then mixed in to form a dough. The dough was then shaped and baked for 25 mins at $100^{\circ} \mathrm{C}$.

\subsection{Determination of nutrient content}

Complementary feeding biscuit was analyzed for carbohydrate content using the difference method AOAC 986.25, fat by Soxhlet method AOAC 920.39, protein by Kjeldahl method AOAC 992.23 and fiber by gravimetry method AOAC 985.29. Iron and phosphorus by spectrophotometry method AOAC 2011.14

\subsubsection{Mineral Content Analysis}

Iron and phosphorus content of the complementary feeding biscuit was determined by spectrophotometry method AOAC 2011.14. Briefly, samples of $2 \mathrm{~g}$ were weighed into the Erlenmeyer flasks and added with 10 $\mathrm{mL}$ of $0.025 \mathrm{~N} \mathrm{H}_{2} \mathrm{SO}_{4}$. Then, $10 \mathrm{~mL}$ of $0.05 \mathrm{~N}$ citric acid was added. Ion-free aquadest of not more than $100 \mathrm{~mL}$ was added until the color becomes clear. The mixture was allowed to stand to cool. The mixture was then transferred into a measuring flask and the residual was rinsed with distilled water. The solution was then filtered with Whatman paper No. 42 and divided into aliquots. The aliquots were then subjected to atomic absorption spectrometry (AAS) and read at wavelength $213.9 \mathrm{~nm}$ (García and Báez, 2012). The mineral content of the samples was calculated using the formula:

$$
\text { Mineral content }\left(\frac{\mu g}{g}\right)=\frac{(a-b) \times v}{w}
$$

Where $\mathrm{a}=$ sample solution concentration $(\mu \mathrm{g} / \mathrm{mL}) ; \mathrm{b}=$ blank solution $(\mu \mathrm{g} / \mathrm{mL}) ; \mathrm{v}=$ sample extract volume $(\mathrm{mL})$; and $\mathrm{w}=$ sample mass $(\mathrm{g})$. 


\subsection{Sensory evaluation}

The organoleptic test of the complementary feeding biscuit using 5-point hedonic test (1: very dislike -5 : Like) to determine the level of preference including color, flavor, texture, and taste was carried out with twenty semi-trained panelists from the Nutrition Science students of Diponegoro University. The average value obtained is then categorized as $<3.00$ included in "dislike" and $>3.00$ included in "like".

\subsection{Statistical analysis}

Data collected were analyzed using one-way ANOVA statistical test with a $95 \%$ confidence level followed by a multiple comparison test (Posthoc test) with the Tukey test to find out the real difference between treatments.

\section{Results}

\subsection{Nutrient content}

The result of the nutrient content of the developed complementary feeding biscuit could be seen in Table 2 . The formulation of yellowfin fish flour and terubuk flour on complementary feeding biscuit significantly affected the level of carbohydrate $(\mathrm{p}=0.000)$, energy $(\mathrm{p}=0.000)$, protein $(p=0.000)$, fiber $(p=0.000)$, and iron $(p=0.002)$, but did not significantly influence the level of fat $(p=0.192)$ and phosphorus $(p=0.061)$. In addition, the developed complementary feeding biscuit followed the requirements of the complementary feeding biscuits based on the decree of the Minister of Health Republic Indonesia on Technical Specifications for Complementary Foods (Ministry of Health Republic of Indonesia, 2007) for energy, protein, fat, and phosphorus content. However, the requirements for fiber and iron content was not met.

\subsection{Physical properties}

The results of complementary feeding biscuit physical properties by substituting yellowfin fish flour and terubuk flour could be seen in Table 3. The formulation of yellowfin fish flour and terubuk flour on complementary feeding biscuits significantly affected the density ( $p=0.027)$ and did not significantly influence the reconstitute $(\mathrm{p}=0.422)$ and texture test $(\mathrm{p}=0.129)$.

Table 1. Ingredients of Formula 1, Formula 2, and Formula 3 (\%)

\begin{tabular}{cccc}
\hline \multirow{2}{*}{ Formulation } & \multicolumn{3}{c}{ Average of Physical Properties } \\
\cline { 2 - 4 } & $\begin{array}{c}\text { Density } \\
(\mathrm{g} / \mathrm{mL})\end{array}$ & $\begin{array}{c}\text { Reconstitution } \\
\text { test }(\mathrm{mL})\end{array}$ & Texture (gf) \\
\hline F1 & $0.64 \pm 0.02^{\mathrm{a}}$ & $20 \pm 5$ & $468.78 \pm 57.79$ \\
F2 & $0.68 \pm 0.02^{\mathrm{ab}}$ & $20 \pm 5$ & $299.55 \pm 34.02$ \\
F3 & $0.70 \pm 0.02^{\mathrm{b}}$ & $25 \pm 5$ & $408.05 \pm 134.17$ \\
$\mathrm{p}$ & 0.027 & 0.422 & 0.129 \\
\hline
\end{tabular}

Note: Different letters behind the numbers indicate significant differences with the Tukey test $\alpha=0.05$.

\subsection{Organoleptic}

The result of complementary feeding biscuits organoleptic with the substitution of yellowfin fish flour and terubuk flour could be seen in Table 4. The formulation of yellowfin fish flour and terubuk flour on complementary feeding biscuit significantly influenced the color $(p=0.033)$, texture $(p=0.002)$ and taste preferences $(\mathrm{p}=0.000)$ but did not significantly influence the flavor preference $(p=0.337)$. The display of three formulation biscuit could be seen in Figure 1.

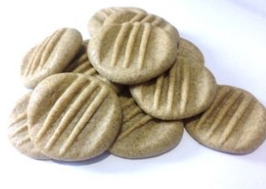

F1

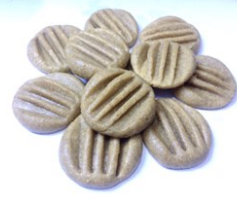

F2

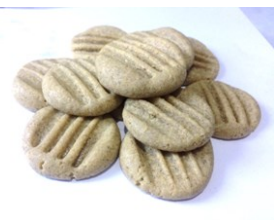

F3
Figure 1. Complementary feeding biscuits of the different formulations

\subsection{Contributions to adequacy of nutrition}

The serving size was determined from the best formulation, F3 beside the highest of nutritional content than the other formulations that presented in Table 5. The serving size must be able to fulfill the one-third of the adequacy of children protein in one consumed.

Table 2. Nutrition content of the complementary feeding biscuit of different formulations.

\begin{tabular}{|c|c|c|c|c|c|}
\hline \multirow{2}{*}{ Nutrient Content } & \multicolumn{3}{|c|}{ Formulation } & \multirow{2}{*}{ Ministry of Health } & \multirow{2}{*}{$\mathrm{p}$} \\
\hline & F1 & $\mathrm{F} 2$ & F3 & & \\
\hline Energy (kcal) & $435.58 \pm 0.66^{\mathrm{a}}$ & $426.85 \pm 0.45^{\mathrm{b}}$ & $436.71 \pm 0.55^{\mathrm{a}}$ & Min 400 & 0 \\
\hline Carbohydrate (g) & $23.19 \pm 0.58^{b}$ & $24.79 \pm 0.42^{\mathrm{a}}$ & $20.45 \pm 0.21^{\mathrm{c}}$ & - & 0 \\
\hline Fat $(g)$ & $20.58 \pm 0.18$ & $20.40 \pm 0.12$ & $20.62 \pm 0.08$ & $10-18$ & 0.192 \\
\hline Protein (g) & $13.86 \pm 0.14^{\mathrm{c}}$ & $15.75 \pm 0.23^{b}$ & $17.33 \pm 0.12^{\mathrm{a}}$ & $8-12$ & 0 \\
\hline Fiber $(\mathrm{g})$ & $26.22 \pm 0.14^{\mathrm{a}}$ & $20.63 \pm 0.23^{c}$ & $25.25 \pm 0.12^{b}$ & Max 5 & 0 \\
\hline Iron (mg/100g) & $3.76 \pm 0.07^{\mathrm{b}}$ & $4.03 \pm 0.05^{\mathrm{a}}$ & $3.68 \pm 0.07^{\mathrm{b}}$ & $5-8$ & 0.002 \\
\hline Phosphorus (mg/100g) & $267.70 \pm 0.31$ & $266.36 \pm 4.24$ & $275.79 \pm 0.36$ & $240-360$ & 0.061 \\
\hline
\end{tabular}

Note: Different letters behind the numbers indicate significant differences with the Tukey test $\alpha=0.05$. 
Table 4 . The results of the organoleptic analysis of complementary feeding biscuit with yellowfin fish meal and terubuk flour

\begin{tabular}{ccccccccc}
\hline \multirow{2}{*}{ Formulation } & \multicolumn{2}{c}{ Color } & \multicolumn{2}{c}{ Flavor } & \multicolumn{2}{c}{ Texture } & \multicolumn{2}{c}{ Taste } \\
\cline { 2 - 9 } & Average & Statement & Average & Statement & Average & Statement & Average & Statement \\
\hline F1 & $3.15 \pm 0.58$ & Like & $3.10 \pm 0.64$ & Like & $2.70 \pm 0.65$ & Dislike & $2.50 \pm 0.60$ & Dislike \\
F2 & $2.85 \pm 0.67$ & Dislike & $3.00 \pm 0.64$ & Like & $2.90 \pm 0.78$ & Dislike & $2.70 \pm 0.73$ & Dislike \\
F3 & $3.40 \pm 0.68$ & Like & $3.30 \pm 0.65$ & Like & $3.45 \pm 0.51$ & Like & $3.50 \pm 0.51$ & Like \\
\hline P & 0.033 & \multicolumn{2}{c}{0.337} & \multicolumn{2}{c}{0.002} & & 0 \\
\hline
\end{tabular}

Note: Different test uses the Kruskall-wallis test.

Table 5. Results of complementary feeding biscuit nutrient content analysis

\begin{tabular}{cccccccc}
\hline \multirow{2}{*}{ Formulation } & \multicolumn{7}{c}{ Nutrient content analysis } \\
\cline { 2 - 8 } & Energy (kcal) & Carbohydrate $(\mathrm{g})$ & Fat $(\mathrm{g})$ & Protein $(\mathrm{g})$ & Fiber $(\mathrm{g})$ & Iron $(\mathrm{mg})$ & Phosphorus $(\mathrm{mg})$ \\
\hline F1 & 435.58 & 23.19 & 20.58 & 13.86 & 26.22 & 3.76 & 267.7 \\
F2 & 426.85 & 24.79 & 20.4 & 15.75 & 20.63 & 4.03 & 266.36 \\
F3 & 436.71 & 20.45 & 20.62 & 17.33 & 25.25 & 3.68 & 275.79 \\
\hline
\end{tabular}

Table 6. Contribution of nutrition formulation 3 per serving of toddler complementary feeding biscuits (45 g) Formulation 3 (F3)

\begin{tabular}{cccc}
\hline Nutrient Content & $\begin{array}{c}\text { Nutrient Content } \\
(45 \mathrm{~g})\end{array}$ & $\begin{array}{c}\text { Adequacy of } \\
\text { Children }\end{array}$ & $\begin{array}{c}\% \text { Contributions to Adequacy of } \\
\text { Nutrition (45 g) }\end{array}$ \\
\hline Energy & $197.3 \mathrm{kcal}$ & $1125 \mathrm{kcal}$ & $17.54 \%$ \\
Carbohydrate & $9.2 \mathrm{~g}$ & $155 \mathrm{~g}$ & $5.93 \%$ \\
Fat & $9.3 \mathrm{~g}$ & $44 \mathrm{~g}$ & $21 \%$ \\
Protein & $7.8 \mathrm{~g}$ & $26 \mathrm{~g}$ & $30 \%$ \\
Fiber & $11.4 \mathrm{~g}$ & $16 \mathrm{~g}$ & $71.25 \%$ \\
Iron & $1.7 \mathrm{mg}$ & $8 \mathrm{mg}$ & $21.25 \%$ \\
Phosphorus & $124.1 \mathrm{mg}$ & $500 \mathrm{mg}$ & $24.82 \%$ \\
\hline
\end{tabular}

Protein was the main consideration because it was needed growth. Based on calculations using the F3 reference, a serving size of $45 \mathrm{~g}$ (4 biscuits) was obtained. Contribution in one serving of complementary feeding biscuit with yellowfin flour and terubuk flour to the nutritional adequacy of children could be seen in Table 6.

\section{Discussion}

\subsection{Nutrient content}

The energy content of the formulations has been fulfilled the requirement based on the Decree of The Minister of Health Republic of Indonesia on Technical Specifications for Complementary Foods (Ministry of Health Republic of Indonesia, 2007). F3 has the highest energy content with $436.71 \mathrm{kcal}$. The energy of a food product is influenced by the protein, fat and carbohydrate content of the food products (Agustia et al., 2017). The complementary feeding F3 biscuit contained the highest energy due to higher fat and protein level compared to the two other formulations.

The fat content in the three formulations was highly $10-18 \%$ despite the requirement complementary feeding biscuit. High levels off at were due to the use of margarine, yolk, and butter. Fat has the function as a shortening to make the biscuit's texture softer (Agustia et al., 2017). In addition, the content of fatty acid also helps the absorption and transportation of fat-soluble vitamins, $\mathrm{A}, \mathrm{D}, \mathrm{E}$, and $\mathrm{K}$ so that if intake is not enough it can cause deficiency of the vitamin.

Protein levels in all three formulations met the requirement. Protein levels in the three formulations increased with the addition of yellowfin fish flour. Protein act as a source of energy, body building agents and regulatory substances in the body that is the growth and maintenance of tissues so that if the protein intake is inadequate children will be more at risk of stunting (Ernawati et al., 2013).

The carbohydrate level does not have a specific requirement. But even so, the right carbohydrate content in the three formulations are still needed because it plays a role in the growth of children as the main energy provider whereby it must be at least 52-54\% (Oktarina and Sudiarti, 2018).

The fiber content of the three formulations was higher than the requirement of complementary feeding biscuit ( $>5 \%)$. F2 had the highest fiber content. With the incorporation of terubuk into the formulation, the fiber content increased due to terubuk is high in fiber. The digestive yield of the fiber is divided into two namely the fermented part which is function as prebiotics such as 
oligosaccharide in breastfeeding and unfermented parts function as softening of feces. Fiber in complementary feeding is usually a fiber from vegetables so that microbiota in the intestine could not ferment at all (Boehm and Danone, 2013). Therefore, the intake of fiber in complementary feeding must be in accordance with the requirements so that the child does not experience digestive system disorder and malabsorption of other nutrients in the intestine.

Due to the baking process $\left(100^{\circ} \mathrm{C}, 25\right.$ mins $)$ which could have depleted the iron level, the iron content of the formulations was not up to the requirement. This is supported by Sundari et al. (2015) that stated high and long thermal process $\left(\geq 100^{\circ} \mathrm{C}\right)$ will reduce the iron levels in food products subjected to it. Inadequate iron intake will cause iron deficiency. Iron deficiency anemia is most often in children where this condition will inhibit the growth and development of the brain, children are more easily sick because of a decreasing in the immune system, as well as delay physical and mental development (Sakinah and Ayustaningwarno, 2013).

On the other hand, the phosphorus level of the three complementary feeding biscuit was supplementary. This was influenced by the substitution of terubuk which contained high phosphorus ( $80 \mathrm{mg} / 100 \mathrm{~g})$. Phosphorus is an important nutrient in the growth, maintenance, repair of damaged body tissue and cooperates with calcium and magnesium in the formation of bone and teeth in infants and children (Sari et al., 2016).

\subsection{Physical properties}

The density of all three formulations met the requirement of the density of powdered food range $(0.30$ - $0.80 \mathrm{~g} / \mathrm{mL}$ ) (Gilang et al., 2013). Food products with high density showed high nutrient density while products with lower density will make children feel full faster. Complementary feeding must have a high density as a high nutritional value density will fill the small volume of space in the intestine of the child and more nutrients will be absorbed. Low density value complementary feeding biscuit will make a child feel full but lack of nutritional requirement (Husna et al., 2012; Gilang et al., 2013).

Reconstitute test is a picture of the ratio of rehydration between the amount of water added to the amount of food in each serving. The amount of water added shall not be too much because it can cause children to be full quickly while energy is not sufficient. This study showed that the increasing content of terubuk flour will require lesser water to dissolve the complementary feeding biscuit to form porridge. This is highly due to high fiber content of the terubuk which absorbs water (Sumardana et al., 2017).

Texture tests were carried out to determine the level of hardness of complementary feeding biscuit product which is associated with crunchiness. The hardness of a biscuit should be between 948-1196 gf, indicating that the texture that is not too hard and not easily broken (Agustia et al., 2017). All three formulations have a hardness level below that range which were 299.55468.78 gf due to the addition of high-fat ingredients used.

\subsection{Organoleptic}

The color of the product is commonly assessed first. If the product has a color that is less attractive to see, even though the taste, texture and aroma are quite good, panelists will consider taking it. The complementary feeding biscuit formulation produced a brownish yellow color. The yellow color in the biscuit comes from the ingredients of yellowfin fish flour, terubuk flour, yolk, margarine and butter. The brown color of the biscuit is influenced by Maillard's reaction during the baking process.

The flavor of the three complementary feeding biscuit formulations is accepted by the panelists due to the influence of the basic ingredients use in the formulation, skim milk, vanilla and the baking process of biscuits which create a savory flavor from margarine. In addition, there was no fishy odor from the yellowfish fin flour. The taste of the formulated biscuit was sweet and savory. The sweet and savory taste come from margarine, yolk, sugar, cornstarch, and yellowfin fish flour. The highest substitute yellowfin fish in complementary biscuits has the highest taste level because amino acid in yellowfin fish makes the biscuit more savory.

The F3 formulation with the highest yellowfin fish substitutes had the best-preferred texture. The other ingredients such as margarine, yolk, sugar and cornstarch will make the biscuit texture soft and crunchy (Wayne, 2013; Claudia et al., 2015).In addition, products with high protein and fat content give the biscuit a crunchy texture due to the fat will prevent water absorption (Zulfa and Rustanti, 2013).

\section{Conclusion}

The three complementary feeding biscuit formulation with yellowfin fish flour and terubuk flour fulfilled the complementary feeding biscuit nutrient content requirement according to the Technical Specifications of Complementary Feeding except the iron content. The preference for complementary feeding biscuit with yellowfin fish flour and terubuk flour 
including color, aroma, taste and texture was acceptable by the adult panelists. Consumption of one serving of complementary feeding F3 biscuits can contribute 30\% of protein adequacy of children aged 1-3 year. Further research is needed to increase the iron content of complementary feeding biscuits made from yellowfin fish flour and terubuk flour in order to meet the technical requirements of complementary feeding biscuit.

\section{Conflict of Interest}

The authors declare no conflict of interest.

\section{Acknowledgments}

The author like to thank all the parties involved and support this study so that it can run smoothly.

\section{References}

Agustia, F.C., Subardjo, Y.P. and Sari, H.P. (2017). Development of biscuit mocaf-arrowroot substituted liver as alternative biscuit with high iron for children under five years. Jurnal Gizi Pangan, 12(2), 129 138. https://doi.org/10.25182/jgp.2017.12.2.129-138

Boehm, G. and Danone. (2013). Soluble and Insoluble Fiber in Infant Nutrition. In Delcour, J.A. and Poutanen, K. (Eds.) Fibre-Rich and Wholegrain Foods., p. 421-449. USA: Woodhead Publishing. https://doi.org/10.1533/9780857095787.4.421

Claudia, R., Estiasih, T., Ningtyas, D.W. and Widyastuti, E. (2015). Development of Biscuit from Orange Sweet Potato Flour (Ipomea batatas L.) and Fermented Corn Flour (Zea mays): A Review. Jurnal Pangan dan Agroindustri, 3(4), 1589-1595.

Ernawati, F., Rosmalina, Y. and Permanasari, Y. (2013). Effect of The Pregnant Women's Protein Intake and Their Baby Length at Birth to the Incidence of Stunting among Children aged 12 Months in Bogor District. Nutrition and Food Research, 36(1), 1-11.

García, R. and Báez, A.P. (2012). Atomic Absorption Spectrometry (AAS). In Farrukh, M.A. (Ed.). Atomic Absorption Spectroscopy. IntechOpen EBook. https://doi.org/10.5772/25925

Gilang, R, Affandi, D.R. and Ishartani, D. (2013). Physical and chemical properties characterization of jack bean (Canavalia ensiformis) flour using pretreatment variation. Jurnal Teknosains Pangan, 2 (3), 34-42.

Husna, E.A., Affandi, D.R., Kawiji. and Anandito, R.B.K. (2012). Study of Millet Flour (Panicum Sp) and Mung Bean Flour (Phaseolus radiatus) Based Instant Baby Porridge With Ambon Banana (Musa paradisiaca Var. Sapientum L.) Natural Flavour.
Jurnal Teknosains Pangan, 1(1), 68-74.

Jayadi, Y.I. and Rahman A. (2018). Analysis of macro nutrition in duo fish (penja) black and white as food local Palu. GHIDZA: Jurnal Gizi dan Kesehatan, 2 (1), 31-38. https://doi.org/10.22487/ ghidza.v2i1.10421

Ministry of Health Republic of Indonesia. (2007). Keputusan Menteri Kesehatan Republik Indonesia N. 224/Menkes/SK/II/2007 tentang Spesifikasi Teknis Makanan Pendamping Air Susu Ibu (MPASI) (Decree of The Minister of Health Republic of Indonesia on Technical Specifications for Complementary Foods). Jakarta: Ministry of Health Republic of Indonesia.

Ministry of Health Republic of Indonesia. (2014). DKBM (Daftar Komposisi Bahan Makanan) (Food Composition Data). Jakarta: Ministry of Health Republic of Indonesia.

Ministry of Health Republic of Indonesia. (2018). Basic Health Research 2018. Jakarta: Ministry of Health Republic of Indonesia.

Oktarina, Z. and Sudiarti T. (2013). Risk Factors of Stunting among Children [24-59 months] in Sumatera. Jurnal of Nutrition and Food, 8(3), 17580. https://doi.org/10.25182/jgp.2013.8.3.177-180

Rachmawati, R. and Ampera, M. (2016). The Organoleptic Characteristics of Biscuit Formulation with Cucurbita moschata, Mucuna prurien, and Metroxylon sago Based. Indonesian Journal of Human Nutrition, 3(1), 91-97. https:// doi.org/10.21776/ub.ijhn.2016.003.Suplemen.10

Sakinah, N. and Ayustaningwarno, F. (2013). Effect of Wheat Flour Substitution with Seaweed Sargassum $s p$ Flour on Nutrient Content and Preference of High Iron Biscuit. Journal of Nutrition College, 2(1), 154 $-161$.

Sari, E.M., Juffrie, M., Nurani, N. and Sitaresmi, M.N. (2016). Protein, calcium and phosphorus intake of stunting and non stunting children aged aged 24-59 months. The Indonesian Journal of Clinical Nutrition (IJCN), 12(4), 156-158. https:// doi.org/10.22146/ijen.23111

Sumardana, G., Syam, H. and Sukainah, A. (2017). Substitution of Banana Tuber Flour into Wet Noodles with the Addition of Dragon Fruit (Hylocereus undatus) Skin. Jurnal Pendidikan Teknologi Pertanian, 3, S145-S157. https:// doi.org/10.26858/jptp.v3i0.5714

Sundari, D., Almasyhuri and Lamid, A. (2015). Effect of cooking process of composition nutritional substances some food ingredients protein source. Media Litbangkes, 25(4), 235-242. https:// 
doi.org/10.22435/mpk.v25i4.4590.235-242

Utomo, N.B.P., Susan and Setiawati, M. (2013). Role of Various Fishmeal Ingredients on Sangkuriang Catfish Clarias Sp. Growth. Jurnal Akuakultur Indonesia (JAI), 12(2), 158-68. https:// doi.org/10.19027/jai.12.158-168

Wayne, G. (2013). Profesional Baking. 6th ed. New Jersey Canada: John Willy and Sons.

World Health Organization. (2012). Interpretation Guide Nutrition Landscape Information System (NLIS) Country Profile Indicators. Geneva, Switzerland: WHO Press. Retrieved on May 24, 2019 from WHO Website: https://apps.who.int/iris/ handle/10665/44397?show=full

Zulfa, N.I. and Rustanti, N. (2013). Nilai Cerna Protein In Vitro dan Organoleptik MP-ASI Biskuit Bayi dengan Substitusi Tepung Kedelai, Pati Garut dan Tepung Ubi Jalar Kuning Protein. Journal of Nutrition College, 2(4), 439-466. [In Bahasa Indonesia]. 